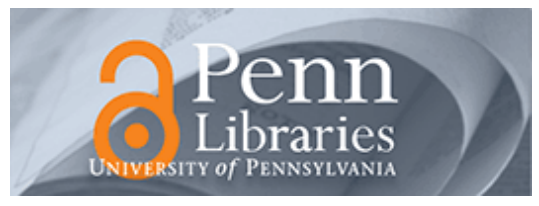

University of Pennsylvania

ScholarlyCommons

\title{
The Role of College Counseling in Shaping College Opportunity: Variations Across High Schools
}

Laura W. Perna

University of Pennsylvania, Iperna@gse.upenn.edu

Follow this and additional works at: https://repository.upenn.edu/gse_pubs

Part of the Accessibility Commons, and the Higher Education Commons

\section{Recommended Citation}

Perna, L. W. (2008). The Role of College Counseling in Shaping College Opportunity: Variations Across High Schools. The Review of Higher Education, 31 (2), 131-159. http://dx.doi.org/10.1353/rhe.2007.0073 


\title{
The Role of College Counseling in Shaping College Opportunity: Variations Across High Schools
}

\author{
Abstract \\ This study draws on data from descriptive case studies of 15 high schools, three in each of five states. \\ The findings highlight constraints in the availability of college counseling, differences in the availability of \\ college counseling across schools, and the influence of schools, districts, higher education institutions, \\ and states on the availability and nature of college counseling. The study suggests that, in the context of \\ limited fiscal and other resources, changes in federal and state financial aid policies, district policies \\ pertaining to counseling, and relationships with higher education institutions will help ensure that all \\ students receive sufficient college counseling. \\ Disciplines \\ Accessibility | Education | Higher Education
}


The Review of Higher Education

Winter 2008, Volume 31, No. 2, pp. 131-159

Copyright (c) 2007 Association for the Study of Higher Education

All Rights Reserved (ISSN 0162-5748)

\title{
The Role of College Counseling in Shaping College Opportunity: Variations across High Schools
}

\author{
Laura W. Perna, Heather T. Rowan-Kenyon, Scott L. Thomas, \\ Angela Bell, Robert Anderson, and Chunyan Li
}

Although college enrollment rates have increased for all groups over the past three decades, gaps across socioeconomic and racial/ethnic groups persist. Students from low-income families, those whose parents have not attended college, and those of African American or Hispanic descent are less likely than those who are more affluent, from more educated households, and White to enroll in college. When students from underrepresented groups do enroll, they tend to be concentrated in public two-year colleges and less selective and less well-resourced four-year colleges and universities (Baum \& Payea, 2004; Ellwood \& Kane, 2000; NCES, 2003, 2004; Thomas \& Perna, 2004).

\footnotetext{
LAURA W. PERNA, is an Associate Professor in the Graduate School of Education at the University of Pennsylvania. HEATHER T. ROWAN-KENYON is Assistant Professor at the University of Virginia. SCOTT L. THOMAS is Associate Professor at the University of Georgia. ANGELA BELL is a doctoral candidate at the University of Georgia. ROBERT ANDERSON is Vice Chancellor of the West Virginia Higher Education Policy Commission. CHUNYAN LI is a doctoral candidate at the University of Pennsylvania. Address queries to Laura W. Perna, the Graduate School of Education, University of Pennsylvania, 3700 Walnut Street, Room 424, Philadelphia, PA 19104; telephone: (215) 746-2522; fax: (215) 573-6069; email: lperna@gse.upenn.edu. Acknowledgements: This research was funded by the Lumina Foundation for Education. The opinions expressed in this paper are those of the authors and do not necessarily represent the views of the Lumina Foundation or its employees. The authors thank Kassie Freeman for her comments on an earlier draft of this manuscript. An earlier version of this paper was presented at the annual meeting of the Association for the Study of Higher Education in November 2006 in Anaheim, California.
} 
Researchers have traditionally focused on two explanations for differences in college access and choice across groups: inadequate financial resources and inadequate academic preparation (e.g., Advisory Committee on Student Financial Assistance, 2002; Perna, 2005; St. John, 2003). More recently, researchers point to other explanations for these gaps, including problems with the alignment between $\mathrm{K}-12$ and higher education curricula and assessments (Venezia, Kirst, \& antonio, 2003; Thomas \& Perna, 2004) and inadequate knowledge and information about college and financial aid (Kane, 1999; Perna, 2004).

One logical source of assistance with problems associated with alignment and information about college and financial aid is the high school counselor (Hamrick \& Hossler, 1996; Horn, Chen, \& Chapman, 2003; Springer, Cunningham, O'Brien, \& Merisotis, 1998). Counselors may be an especially important source of assistance and information for Blacks, Latinos, low-income students, and students whose parents do not have direct experience with college (Perna, 2004; Tomás Rivera Policy Institute, 2004; Tornatzky, Cutler, \& Lee, 2002). For example, Latino parents and students report preferring high school counselors over other sources of college-related information (Tomás Rivera Policy Institute, 2004).

Nonetheless, a review of the available data and research suggests severe structural constraints on the availability of high school counselors to provide college counseling (McDonough, 1997, 2005a). Although the American School Counselor Association's recommended student-to-counselor ratio of 100:1 admittedly reflects some degree of self interest, the 2004 national average of 262:1 is astonishingly high, especially when considering that this figure includes large public as well as much smaller independent schools (McDonough, 2005a). Student-to-counselor ratios are typically higher in public than in independent high schools, and increase with the total enrollment of the high school (NACAC, 2006).

Because of fiscal constraints and other priorities, most schools cannot simply hire more counselors. One survey shows that, between 2004 and 2005 , the number of counselors remained unchanged at $86 \%$ of high schools, declined at $4 \%$ of high schools, and increased at only $9 \%$ of high schools (NACAC, 2006). In a notable exception to this trend, in July 2006 the California state legislature decided to allocate \$200 million to increase counseling services to students in grades 7 through 12 . This block grant program is intended to help bring current student-to-counselor ratios (500:1 in the middle schools and 300:1 in the high schools) closer to the national average (California Association of School Counselors, 2006a). To receive funds (about $\$ 67$ per student), school districts must implement a school counseling program that includes "individualized review of student academic progress," increased counseling services to students at risk of not 
graduating from high school, and increased assistance to students at risk of failing to pass the California High School Exit Exam (California Association of School Counselors, 2006b). Moreover, the legislature requires that funds supplement, not replace, existing counseling resources. Regardless, because of its focus on high school completion and because of the high studentto-counselor ratios that currently exist, the California funding initiative will likely help address the shortage of school counseling services but will not ensure that sufficient numbers of counselors are available to meet all students' college-specific counseling needs.

Therefore, in the context of fiscal and other constraints, this study examines the ways that the state, district, and school context shape the availability and nature of college counseling in U.S. public high schools. The findings highlight constraints on the availability of college counseling, differences in the availability of college counseling across schools, and the influence of schools, districts, higher education institutions, and states on the availability and nature of college counseling at a school. The study suggests, given the context of limited resources, that structural changes (including changes in federal and state financial aid policies), district policies pertaining to counseling, and relationships with higher education institutions are required to ensure that all students receive sufficient college counseling.

\section{LITERATURE REVIEW}

School counselors help create a school's college-going culture and shape students' and parents' perceptions and expectations of potential college options (McDonough, 1997, 2005b). Counselors can influence students' aspirations for and understandings of college, academic preparation for college, and college-related decisions, as well as parents' support for their children's college aspirations (McDonough, 2005a, 2005b).

\section{Challenges}

Counselors face many challenges in their efforts to provide college-related counseling. First, college counseling is just one of a counselor's responsibilities. School counselors also engage in crisis intervention counseling, developmental counseling, scheduling, test administration, and discipline (Ballard \& Murgatroyd, 1999; McDonough, 2005a; NACAC, 2006; Venezia \& Kirst, 2005). The availability of college counseling is also limited by the dual role of counselors as mentors and gatekeepers, the short-term duration of interactions between counselors and students, and barriers that limit the development of "trusting" relationships between counselors and students, especially working-class minority students (Stanton-Salazar, 1997).

Although no available data describe the share of time that counselors spend on college counseling (McDonough, 2005a), several descriptive studies 
document widespread frustration with the availability of college-counseling services. Such studies show that students (Libsch \& Freedman-Doan, 1995), parents (Chapman, DeMasi, \& O'Brien, 1991), and teachers (Beesley, 2004) believe that counselors should be devoting more time to providing direct services to students, particularly college-related counseling. Other research (e.g., Rosenbaum, 2001; Rosenbaum, Miller, \& Krei, 1996) suggests that high school counselors too often encourage a "college-for-all" approach, at the expense of providing sufficient information about the academic preparation and achievement that are required during high school, alternatives to college, or students' chances of succeeding in college.

Another challenge is that training in college counseling is often not part of a school counselor's formal education, as college counseling has traditionally been viewed as inconsistent with a counselor's focus on students' mental health (McDonough, 2005a, 2005b). Counselors may also experience role ambiguity (i.e., unclear understanding of job priorities), role conflict (i.e., differences in expectations from administrators, teachers, and students), and role congruity (Freeman \& Coll, 1997). Freeman and Coll concluded that role congruity (i.e., tensions between the magnitude of assigned responsibilities and constraints on available resources to accomplish their responsibilities) is relatively unique to school counselors.

\section{Determinants of College Counseling Availability}

Based on their examination of 23 schools in six states, Venezia and Kirst (2005) concluded that the availability of college counseling and other collegerelated resources varies greatly across and within schools. Within schools, college counseling is more common for students in Advanced Placement, honors, and college preparatory curricular tracks than for students in other tracks (McDonough, 2005a; Venezia \& Kirst, 2005). The nature of college advising also varies based on students' characteristics, as counselors are more likely to encourage students of higher socioeconomic status than students of middle and lower socioeconomic status to attend a four-year college or university (Linnehan, 2006). College-related counseling is also less available in schools with predominantly low-income and/or minority student populations than in other schools (McDonough, 1997, 2005a).

McDonough's (1997) examination of college-related decision-making for students attending four high schools in California provides a window into the structure of college-counseling within and across schools, and the ways that school-specific characteristics, including school policies, resources, and structures, contribute to the availability and nature of college counseling. For example, McDonough's work suggests that the availability of college counseling reflects a school's "organizational environment for college choice decision-making," as manifest by school support for academic preparation and college counseling as well as the extent to which college-going is part of a school's mission. 
Although we know a fair amount about the challenges that limit the availability of college counseling in the context of the school, we know relatively little about the ways that external forces, including federal, state, and district policies and a school's relationships with higher education institutions, shape the quantity and quality of college counseling within a school. This study is designed to address that knowledge gap.

\section{Conceptual Framework}

Understanding the influence of contextual forces on the provision of college-related counseling requires the use of a multi-level conceptual model. This inquiry is guided by the multi-level conceptual model developed by Perna (2006) and refined by Perna and Thomas (2006). Designed for examinations of the contextual forces that shape student outcomes and developed based on a comprehensive review and synthesis of prior research, the multilevel conceptual model draws on multiple theoretical perspectives and situates the college-enrollment decision-making process within several layers of context (Perna, 2006). Like "the student choice construct" (Paulsen \& St. John, 2002; St. John \& Asker, 2001), the conceptual model assumes that college-related behaviors reflect an individual's "situated context." Specifically, the conceptual model assumes that students' college-enrollment decisions are shaped by four nested contextual layers: the student and family context; the school and community context; the higher education context; and the broader social, economic, and policy context. For this study, the model assumes that the structure and availability of counseling at a school shapes students' opportunity for college but that the structure and availability of counseling at a school is shaped directly and indirectly by other layers of context, including the federal and state policy context, the higher education context, and other aspects of the school context. While McDonough (1997) sheds light on the former set of relationships (i.e., the ways that the structure and availability of counseling at a school shape students' college choices), this study focuses on the latter (i.e., the external forces that shape the provision of college counseling at a school).

This multi-level model, and the review of research on which the model is based, suggests that the most important student-level predictors of college enrollment are academic preparation and achievement, financial resources, knowledge and information about college, and family support (Perna, 2006). The small number of studies that examine linkages among particular levels of context and students' college enrollment decisions show the role of various aspects of context, including schools, colleges, and states. For example, research shows that students' college enrollment decisions are influenced by the quality and quantity of counseling and other resources at the high 
schools they attend (McDonough, 1997; Perna \& Titus, 2005), passive and active efforts by higher education institutions to transmit college-related information to students (McDonough, antonio, \& Trent, 1997), and state policies pertaining to $\mathrm{K}-12$ education, higher education appropriations, and need-based financial aid (Perna \& Titus, 2004).

\section{Research Method}

Reflecting the conceptual model's attention to various layers of context, this study uses multiple descriptive case studies to address the following three research questions:

1. What is the availability of college counseling at selected high schools?

2. In what activities do counselors at different schools engage with the goal of promoting college opportunity?

3. How do external entities, including school districts, higher education institutions, and states, shape the availability of college counseling at different schools?

To address these questions, we use data from descriptive case studies of 15 high schools, three in each of five states. The conceptual model and research design view the state as one unit of analysis and the high school as an embedded unit of analysis (Yin, 2003a). Case study methodology is appropriate given our interest in understanding how different forces shape counseling and because of our focus on the "contextual conditions" that shape college opportunity (Yin, 2003b).

The five states in the analyses are California, Florida, Georgia, Maryland, and Pennsylvania. We purposively selected these states because of their variation on a number of demographic, economic, political, and educational characteristics. For example, the racial/ethnic composition of the states' college-eligible populations varies, with Blacks representing a higher share of high school graduates in 2001-2002 in Georgia (33\%) and Maryland (33\%) than in Florida (20\%), Pennsylvania (10\%), and California (7\%) (WICHE, 2003). Hispanics represent a substantially higher share of high school graduates in California (33\%) and Florida (17\%) than in Georgia (2\%), Maryland (4\%), and Pennsylvania (3\%) (WICHE, 2003). The five states also vary in terms of their orientation to student financial aid. In Florida and Georgia, about two-thirds of all state grant aid to undergraduates is awarded based only on merit, compared with none of the state grant aid awarded in California or Pennsylvania, and 5\% of the grant aid in Maryland (NASSGAP, 2007). State grant aid is relatively more plentiful in Georgia (third highest among the 50 states in state grants per 18-24-year-old population) and relatively less plentiful in Maryland (27h of 50 states) (NASSGAP, 2007). 
To select the 15 high schools, we first constructed a demographic and academic profile of all public high schools in each of the five states. We developed indicators for these profiles using data from the Common Core of Data, the U.S. Census Bureau, and each state's department of education. We then used the demographic and academic profiles to identify school districts and/or metropolitan areas with at least three high schools with varying demographic and academic indicators. Selecting three high schools in one district or metropolitan area helps to control for alternative explanations for observed differences across schools, including the media, proximity to colleges and universities, and characteristics of the local labor market.

The three high schools in each state have varying demographic and academic characteristics. Specifically, one of the three schools has above average student achievement and socioeconomic status, one has average student achievement and socioeconomic status, and one has below average achievement and socioeconomic status. Table 1 shows that, within each state, the share of White students is positively related, and the percentage of students participating in the federal free and reduced price lunch program is inversely related, to our "resource" designation of the school. Also in each state, such indicators of academic readiness for college as SAT test-taking rates, average SAT scores, and pass rates on the state math and reading assessments increase with the school's resource designation. Table 2 shows that, in all five states, four-year college enrollment rates increase with the resource designation, regardless of whether they are measured as actual enrollment rates of the school's graduates or the documented decisions of the school's 12th graders.

\section{Data Collection and Analyses}

Reflecting Yin's (2003a) emphasis on the role of theory in guiding case study research, we developed data collection protocols based on the conceptual framework and a review of what is known from the literature about the predictors of college enrollment. The use of these protocols helped ensure comparability of data collection procedures across the 15 schools (Yin, 2003a). Part of a larger study of the influence of federal, state, and local policies that shape college opportunity, the protocols included such questions as: What public policies and programs are designed to promote college opportunity for students attending this school? What are the perceived and actual college-related outcomes? What are the barriers to college opportunity for students attending this school? How do counselors, teachers, and parents promote and impede college opportunity?

The research team completed the protocols using multiple sources, including the demographic and academic school profiles; a review of the federal, state, and local policies in each state; and individual and focus group interviews. At each school, the research team conducted focus groups with 


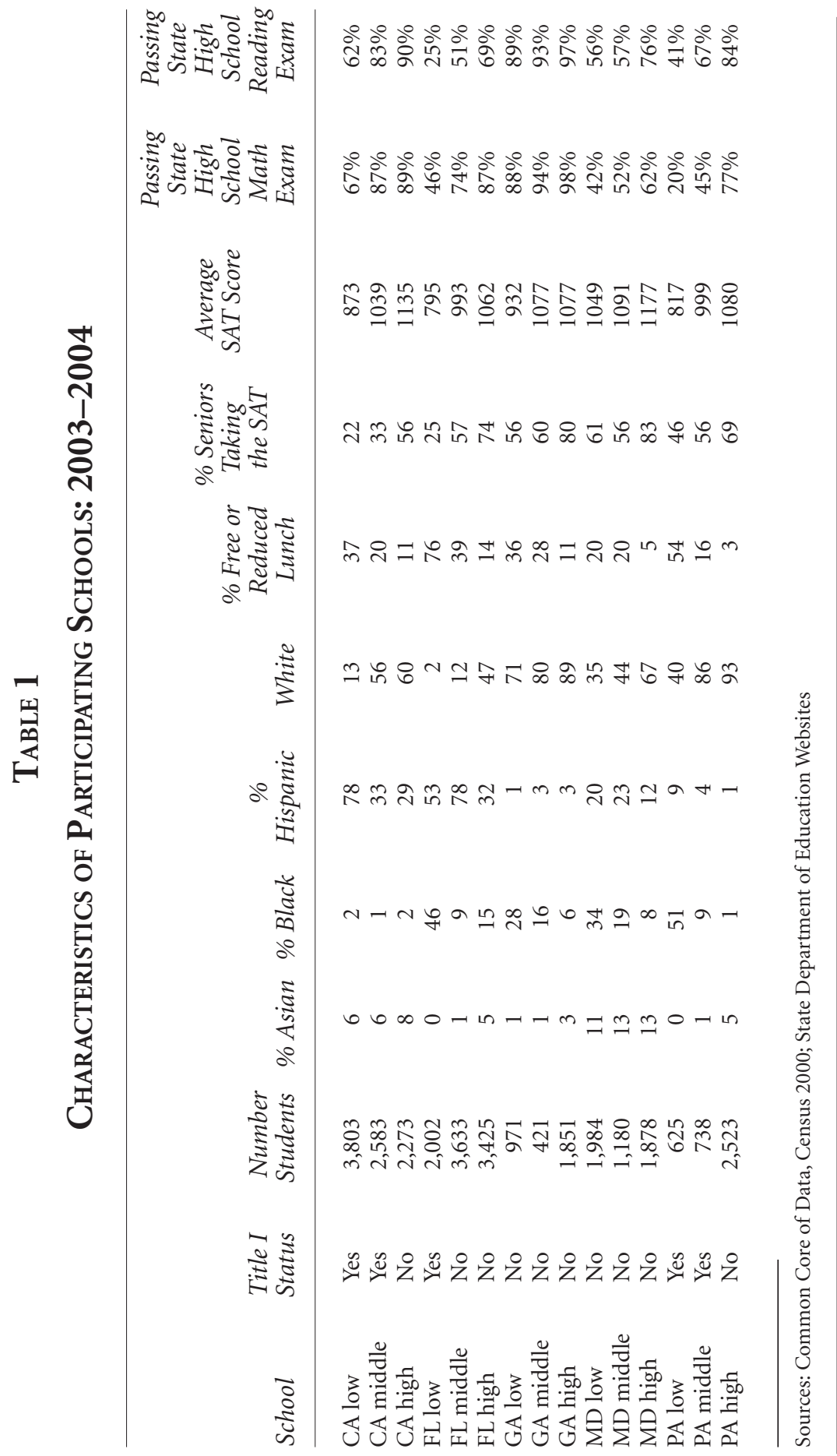




\section{TABLE 2}

\section{Postsecondary Plans and Enrollments at 15 Study SCHOOLS}

\begin{tabular}{|c|c|c|c|c|}
\hline \multirow[b]{2}{*}{ Study School } & \multicolumn{2}{|c|}{$\begin{array}{l}12^{\text {th }} \text { Graders Going to: } \\
\text { (Documented Decisions) }\end{array}$} & \multicolumn{2}{|c|}{$\begin{array}{c}\text { \% Graduates Going to: } \\
\text { (Actual Enrollment) }\end{array}$} \\
\hline & Four-Year & Two-Year & Four-Year & Two-Year \\
\hline California low & $9 \%$ & $26 \%$ & $10 \%$ & $29 \%$ \\
\hline California middle & $10 \%$ & $35 \%$ & $10 \%$ & $38 \%$ \\
\hline California high & $20 \%$ & $48 \%$ & $21 \%$ & $50 \%$ \\
\hline Florida low & $8 \%$ & $31 \%$ & $11 \%$ & $42 \%$ \\
\hline Florida medium & $25 \%$ & $40 \%$ & $24 \%$ & $39 \%$ \\
\hline Florida high & $34 \%$ & $27 \%$ & $37 \%$ & $29 \%$ \\
\hline Georgia low & $21 \%$ & $3 \%$ & $26 \%$ & $3 \%$ \\
\hline Georgia medium & $42 \%$ & $1 \%$ & $46 \%$ & $1 \%$ \\
\hline Georgia high & $58 \%$ & $3 \%$ & $62 \%$ & $3 \%$ \\
\hline Maryland low & $44 \%$ & $19 \%$ & & \\
\hline Maryland medium & $50 \%$ & $14 \%$ & & \\
\hline Maryland high & $72 \%$ & $9 \%$ & & \\
\hline Pennsylvania low & $28 \%$ & $17 \%$ & & \\
\hline Pennsylvania medium & $37 \%$ & $22 \%$ & & \\
\hline Pennsylvania high & $65 \%$ & $23 \%$ & & \\
\hline
\end{tabular}

Sources: California Department of Education, Florida Education and Training Placement Information Program, University System of Georgia High School Feedback Reports, State Department of Education Websites

9th grade students, 11 th grade students, 9 th grade parents, and 11th grade parents and semi-structured interviews with teachers and counselors. Each focus group and interview lasted between 45 and 90 minutes. The individual interviews and focus groups were audio-recorded and transcribed. Between 20 and 58 students, teachers, counselors, and parents at each school participated in the study, for a total of 596 participants.

To analyze the data, we first created a case study database to organize the information that we collected (Yin, 2003b). The database included transcriptions from the focus groups and interviews, as well as data from the policy analyses and demographic and academic profiles. We developed a preliminary list of codes using the conceptual framework and knowledge of prior research, while also allowing additional codes to emerge. We em- 
ployed HyperResearch software to assist in the coding and compiling of data into categories.

We used several strategies to ensure the trustworthiness and credibility of the findings and conclusions. To ensure construct validity, we collected information from multiple sources including participants with different perspectives (i.e., students, parents, teachers, and counselors) (Yin, 2003b). We also established a chain of evidence (Yin, 2003b). In addition, we produced a draft case study report for each school and asked the primary contact at each school (a school counselor) to review the report and provide feedback (Yin, 2003b). We used multiple members of the team to evaluate the coding and categories and to ensure inter-rater reliability. The use of the case study protocol and case study database also helps ensure reliability (Yin, 2003b).

\section{Limitations}

Despite the strengths of the research design, the study has several limitations. First, although the study provides an in-depth understanding of the availability of college counseling and the ways that districts, higher education institutions, and states shape college counseling, these findings are based on data describing just 15 schools in only five states. Therefore, the generalizability of the findings to other schools and states is limited.

Second, we focus on the role of school counselors and counseling-related activities in the provision of college counseling, with little attention to the ways that other school structures shape college counseling and are shaped by districts, higher education institutions, and states. Such programs may include Advanced Placement, as well as programs that link high schools to colleges and universities (e.g., dual enrollment). Finally, the study examines the role of the state policy context in shaping the availability of college counseling at a school but does not include attention to the full range of state policies that may play a role. Although important, these limitations do not reduce this examination's usefulness in how external forces shape the quantity and quality of college counseling in American public high schools.

\section{FINDINGS}

\section{Availability of College Counseling}

Like some other research (e.g., Ballard \& Murgatroyd, 1999; McDonough, 2005a; NACAC, 2006; Venezia \& Kirst, 2005), the analyses show that collegerelated counseling is limited not only because of high student-to-counselor ratios, but also because of other school and counselor priorities. The magnitude of constraints on providing college counseling varies across schools based on the characteristics of the students the schools serve and the location of schools in particular districts or states. 


\section{TABLE 3}

\section{School Counseling Resources at the 15 Study Schools}

\begin{tabular}{lccc}
\hline School & $\begin{array}{c}\text { Number of } \\
\text { Counselors }\end{array}$ & $\begin{array}{c}\text { Number of } \\
\text { Students per } \\
\text { Counselor }\end{array}$ & $\begin{array}{c}\text { Designated } \\
\text { College } \\
\text { or Career } \\
\text { Coordinator }\end{array}$ \\
\hline $\begin{array}{l}\text { California low-resource } \\
\text { California middle-resource }\end{array}$ & 9 & 475 & Yes \\
California high-resource & 7 & 369 & Yes \\
& 5 & 455 & Yes \\
Florida low-resource & 4 & 501 & Yes \\
Florida middle-resource & 9 & 404 & Yes \\
Florida high-resource & 7 & 489 & Yes \\
& 2 & 486 & No \\
Georgia low-resource & 1 & 421 & No \\
Georgia middle-resource & 4 & 463 & Yes \\
Georgia high-resource & & & Yes \\
& & 233 & Yes \\
Maryland low-resource & 8.5 & 215 & Yes \\
Maryland middle-resource & 5.5 & 235 & No \\
Maryland high-resource & 8.0 & 213 & No \\
Pennsylvania low-resource & 2 & 185 & No \\
Pennsylvania middle-resource & 4 & 315 &
\end{tabular}

Note: Number of counselors includes all staff with general or college-specific counseling or advising duties, including counselors, guidance technicians, and college and career counselors. Source: Interviews with counseling staff at the high schools.

1. Student-to-counselor ratios. Even when considering all staff with general and college-specific responsibilities, the ratio of students to counselors exceeds the American School Counselor Association's ratio of 100:1 at all 15 of the study schools. Table 3 indicates that the average number of students per counselor varies across states, with lower student-to-counselor ratios at participating schools in Maryland and Pennsylvania, and higher ratios at participating schools in California, Florida, and Georgia. Consistent with other descriptive data (NACAC, 2006), student-to-counselor ratios do not seem to be related to the characteristics of the student body. Table 3 shows that the student-to-counselor ratio is comparable at the low- and high-resource schools in Maryland, lower at the low-resource schools in 
Pennsylvania than at their high-resource counterparts, and higher at the low-resource schools in California, Florida, and Georgia than at their highresource counterparts.

Study participants note the challenges associated with these high ratios. The words of a counselor at the Georgia low-resource school are representative:

It's overwhelming and it's unreal-the counselor to student ratio. And, you know, everybody — the teacher, the administrators, the community-expects all the answers to come from the counseling office. And with a ratio of 500 or 600 to one, that's not really that possible. (counselor, Georgia, low-resource school)

2. Variations in availability of college counseling based on students served. At all schools, at least some participating students, parents, and teachers praise counselors' efforts to provide college-related counseling. Some participants indicate that counselors provide critical assistance with college-related processes and "bend over backwards" to assist students.

Yet while acknowledging counselors' efforts, participants at all schools believe that the availability of counselors for college-related assistance is insufficient. Counselors identify several forces that limit their time for college-counseling, including budget cuts (California, low-resource school), such responsibilities as administering tests (Georgia, low-resource school), complying with data-reporting demands (Georgia, low-resource school; Maryland, middle-resource school; Maryland, high-resource school), and identifying and assisting students with mental health, drug, and alcohol problems (Pennsylvania, low-resource school; Pennsylvania, high-resource school).

Because resources are scarce, participants at several schools indicate that most activities are oriented toward meeting the needs of the average and/or most needy students. But a focus on serving these students likely results in fewer college-related services for other students, particularly college-eligible students who attend schools where college is not the norm (i.e., the low-resource schools in this study). In the words of a counselor at the low-resource school in Pennsylvania: "I don't spend a lot of time on the college bound and the honors kids. I spend very little time with them. They're all bright, they know how to do all this, they don't need me."

Even when counselors attempt to target the most disadvantaged students for scarce college-counseling resources, available resources are often insufficient. At the Florida low-resource school, counselors particularly target students who are at risk of failing to pass the state-mandated exit examination. But, explains the college counselor, even with this targeting, not all students are adequately served: 
We've been calling them [ninth graders with low reading scores] out one-on-one and talking with them.... Most of them are immigrants.... So then we explain to them how college works in this country.... That's been pretty good except we can't see all of them because we can only see about 10 or 15 on a Wednesday and there are a lot of ninth graders in the Intensive Reading [program]. (college counselor, Florida, middle-resource school)

3. School goals for college counseling. The relative emphasis that a school places on college counseling varies based on both the characteristics of students attending the school and the school district in which the school is located. At the low-resource schools, other priorities (e.g., ensuring that students graduate from high school) seem more important than promoting college enrollment. For example, a counselor at the Maryland low-resource school says: "I don't think we get enough time to spend with those 11th and 12th graders because we've got, you know, the 12th graders that we're struggling just to get graduated." In contrast, at the high-resource Maryland school, school counseling staff organize activities to provide "a very handson approach" to students' college-related activities.

Ten of the 15 schools that we visited have a dedicated college and career coordinator. In the schools in Florida and Maryland, such a position exists because of district-level policies. Each of the three California schools also has a college and career center and coordinator, but these positions exist in only nine of more than 15 high schools in the county. No similar district policy exists for the schools in Georgia or Pennsylvania. Perhaps reflecting the absence of a district policy, only one of these six schools has a college and career center and coordinator (i.e., the Georgia high-resource school).

Where present, the college and career coordinator is responsible for the college and career center and leads college counseling activities in the schools. These individuals focus exclusively on college- and career-related activities. The words of a coordinator at the Florida low-resource school are typical, "My job is specifically college, period.... My job is to get you into college. Have you taken your tests, financial aid, scholarships, the whole nine yards."

A college and career center provides a highly visible location where students can seek information and advice about college. A counselor at the California low-resource school explains: "Students see [the college center] as a place that they can come and really get the right information and get assistance that they need." While the college center is a resource for all students, the benefits may be greater for students without sufficient support from their families. A counselor at the California low-resource school states: "What I find is that the kids who do not have a lot of supports at home are the ones who need that support from the counselor and the career center coordinator." 
4. Consequences of high student-to-counselor ratios. One consequence of the high student-to-counselor ratios and non-college-related demands is that counselors at all participating schools are simply too overloaded to fully achieve their advising goals and meet the expectations of students and parents. For instance, advising tends to occur in small groups rather than in one-on-one meetings and for shorter periods of time. In addition, despite their best efforts, counselors recognize that they "certainly miss kids, even among our college prep kids, every year" (counselor, California, low-resource school). When asked for suggestions to improve college opportunity, participants at all schools call for additional resources to provide more oneon-one advising. The recommendation of a counselor at the high-resource Pennsylvania school is representative: Schools need "to lighten the load, so that we could spend even more time with students."

A second consequence of the high student-to-counselor ratios is that students and/or parents must take the initiative to obtain college-related assistance. At all but one of the study schools, counselors require students and parents to make an appointment even for "quick questions." At only the Pennsylvania low-resource school did counselors report being available to students and their families "on demand." The "on demand" strategy may ensure that students' information requests are met, but it also limits the extent to which counselors may proactively provide college- and other counseling services. A counselor at the low-resource Pennsylvania school explains:

I never have parents make appointments. They just show up- "I need to see you." Same with my students. Students show up, "Hey, I got to talk to you." ... And I found that if I say to the student, "You better go back and get a pass and then come back to see me," I never see them again. So I'm more flexible with that. I deal with chaos all day. My day is governed by constant interruption.

While students, parents, and counselors at all types of schools (i.e., low-, middle-, and high-resource schools) described the importance of student initiative in acquiring college-related counseling, the prevalence of this knowledge may be an artifact of the characteristics of student participants. In other words, students and families who agreed (i.e., self-selected) to participate in this study may be more aware of the need to initiate contact with counselors than others at these schools.

Comments from participants at two of the five low-resource schools suggest that at least some students attending these schools may be unwilling "to make the effort" to initiate contacts with their counselors and/or lack confidence in the ability of counselors to serve their needs. In the words of an 11th grader at the Georgia low-resource school:

I just feel like our counselors don't do enough for us. Like I don't necessarily feel like we should go up there and try to have to talk with them. We're all 
juniors, and if you want all of us to go to college you need to try to make the effort to help us to get into college instead of making us have to try to come see you, and then we have classes and most of the time we can't even get to talk to them anyway.

And from a ninth grader at the Florida low-resource school:

It's usually just the parents tell you [about financial aid] because you don't really get to meet up with the counselors all that much, because sometimes they won't be here to tell you about the things that you need to know about college.

\section{Counselors' College-Related Activities}

Like other descriptive studies (e.g., NACAC, 2006), this study shows that counselors engage in many activities designed to assist students with college-related processes while also engaging in numerous non-college-related tasks. These activities include having one-on-one meetings with students and/or parents, visiting classes to discuss college-related issues, conducting evening programs on financial aid and other topics, organizing visits to the school from representatives of colleges and universities, and leading tours of student groups to participating colleges and universities. Unlike other studies, the analyses reveal differences across schools in the delivery of college-related services, particularly in terms of the targeting and content of financial aid information and intensity of financial aid assistance, as well as the ways that counselors use teachers to supplement counselors' collegecounseling efforts.

1. Teaching and content of financial aid information. Counselors adapt the orientation of financial aid information to reflect both the characteristics of the student body and the state financial aid context. In terms of the former, counselors at a few schools, especially schools in California and the low-resource school in Maryland, report working to provide information to students and their families in both English and Spanish. This orientation is not surprising, given that Hispanics represent sizeable shares of the student bodies of these schools. (See Table 1.)

The content of financial aid advising varies based on whether a school is located in a state with a large merit-based aid program — namely, Florida and Georgia. In these two states, unlike the situation in other states, financial aid advising is linked to academic advising. Specifically, counselors in Florida and Georgia are working to ensure that students meet the academic eligibility requirements for at least one of the state's non-need-based financial aid programs. In the words of a counselor at the Florida low-resource school:

In some instances [even] your bright students [do not know whether they qualify for the program.] But that's where our role, you know, kicks in as coun- 
selors. Because as we're scheduling students, we try to make sure that we give them enough vocational classes so that if that GPA does get to a certain point, that they automatically qualify [for the Bright Futures vocational award].

The availability of non-need-based financial aid may be empowering, as one counselor suggests that students can improve their eligibility for meritbased aid but not need-based aid. In the words of a college counselor at the Florida, middle-resource school:

We tell them that there are-you can receive money based on merit and you can receive money based on your family income, and sometimes you can receive both.... You don't have much control over your family's income but you do have control over the merit-based. So you work hard, you do what you need to do, and then when you're a senior and you apply for financial aid that would be based on your parents' income.

In addition, because the award criteria are simple and transparent, counselors in Georgia and Florida feel more confident in advising students on the availability of state aid to help pay college prices and, as necessary, help students to identify alternative methods for financing college expenses. A counselor at the low-resource Georgia school explains:

In my first senior interview, I go ahead and I calculate their $\mathrm{HOPE}^{1}$ so they know where they stand. And they think, a lot of them, they don't understand how averages work and understand how GPAs work and they think if, "Oh, if I do really good in my classes I can pull it up." Well, I'll go ahead and I'll plug it in. I'm like, "If you made 100 in the next three classes you're still not going to have HOPE. So it's safe to say that you don't qualify for HOPE, so we need to be making other plans." So I go ahead and let them know that up front so they can have plenty of time, a whole semester to plan what are they going to do.

Because of the simplicity of the award criteria, teachers in Florida and Georgia are also able to supplement counselors' efforts to communicate with students about their eligibility for state aid. A teacher at the Georgia middle-resource school says:

I think that everybody on faculty knows, at a bare minimum, what to be able to tell them. I mean, what you need to get HOPE and, ah, even if you're going to a technical school. I mean, I think we all know at least a little bit to tell them, if not all the details.

${ }^{1} \mathrm{HOPE}$ (Helping Outstanding Pupils Educationally) is a scholarship and grant program offered by the state of Georgia to reward students who meet the academic eligibility requirements and attend an eligible college in Georgia. 
In contrast, teachers at schools in other states tend to refer financial aid questions to the counselors. In the words of a teacher at the California high-resource school:

I'm not knowledgeable on, you know, specifically how to fill out a FAFSA and, you know, what scholarships are available. You know I read the bulletin to the kids, but I really direct them to go meet with their counselor.

2. Intensity of assistance. At all schools, participants describe the availability of passive forms of financial aid information dissemination such as posters, pamphlets, books, and websites, as well as mentions in the daily announcements and parent newsletters. All schools also conduct annual financial aid nights for students' families.

Unlike at most other schools, the college counselors in the Florida schools also offer intensive, one-on-one assistance with financial aid applications. At the high-resource Florida school, the college counselor "just come[s] into the library for two weeks every lunchtime and the kids can come in or the parents can come in and we can work on financial aid." The college counselor will also meet "privately" with students and/or their families to "actually fill out the FAFSA and submit it." At the low-resource Florida school, the college counselor requires students to participate in a financial aid workshop "through the classroom." The college counselor explains:

They physically get a [FAFSA form and Florida Bright Futures application] ... and I make them fill it out, so when they leave the only part that is missing is the income information from their parents or theirs if they worked.... I take them on the Internet and they have to apply for a PIN number for them.... I explain the electronic signature. We go through the whole kit and caboodle.

While counselors in Maryland and Pennsylvania work to encourage students in their schools to apply for local scholarships, counselors at schools in Florida and California report actively seeking out potentially eligible students to complete applications for state financial aid programs. Counselors in California and Florida have students complete actual Cal Grant Form and Bright Futures applications, respectively.

The analyses suggest three potential reasons for the absence of such intensive financial aid assistance from counselors at participating schools in Georgia, Maryland, and Pennsylvania: insufficient counseling resources, lack of training in financial aid, and complex financial aid application processes. In terms of insufficient counseling ratios, comments from a counselor at the Pennsylvania, high-resource school are representative: "We do not get involved with PHEAA forms here at school with parents. We don't sit down and fill them out with them. We don't answer their questions. We just can't. We have too many students." 
A second constraint on providing financial aid advising is that not all counselors feel prepared to provide financial aid counseling or have the ability to engage in ongoing professional development to acquire such expertise. In the words of one counselor:

I'm not trained in [financial aid counseling]. That's not part of my graduate degree. ... My graduate degree is primarily counseling, with a little bit of school stuff in it. ... This is my second year at counseling seniors, so, you know, the college process is just sort of reading stuff, word of mouth, hearing from other things, doing my own research.... There are a lot of opportunities to go to workshops.... But, I mean, I have two young children so I don't go on college visits. I mean, I just can't get away from home at this point in my career. (counselor, Maryland, high-resource school)

The complexity of federal financial aid processes and some state financial aid processes, as well as differences in financial aid packaging across institutions, also limit counselors' ability to assist students. Counselors report: "If you phone two different [colleges and universities] you're going to get two different answers" (counselor, California, low-resource school). They also call the FAFSA form "tough" (counselor, Georgia, high-resource school) and "confusing" (counselor, Maryland, high-resource school). A counselor from the Georgia middle-resource school reports being advised not to assist students with completing FAFSA applications, stating: "And I know from the conferences I've been to, they said, 'Do not.' They said, 'The ones we get, unless you've been specifically trained in that, are usually wrong."”

3. Use of teachers to provide college counseling. In most schools, teachers play a limited role in providing college counseling to students. For example, when asked about the availability of programs to promote college enrollment for students at the school, a teacher at the California high-resource school states: "I plead ignorance here. My assumption would be that the counselors are on it, if there are programs out there. We have a very dedicated professional staff." At some schools, assistance with college counseling seems to be at the discretion of individual teachers. For instance, teachers at the Georgia low-resource school and Maryland low-resource school indicate that some teachers invite counselors into the classroom to speak with students about college and career information.

In some schools, counselors work with teachers to systematically infuse college-related information into the curriculum, particularly into English classes. In Maryland, the district requires that all 12th grade students write a college application essay in their English classes. In the Florida middleresource school, the English Department coordinates completion of a portfolio, with activities that span from ninth through 12th grades. A counselor explains that the portfolio "includes resumés, also about their community service, quality of work, if they've ever interviewed with the military. It's 
got many different aspects to it, so it's sort of like a capsule of what they did in high school in one place." The California middle-resource school incorporated a "six-year plan" into the English curriculum. The plan covers "six years of information," from eighth grade through to the "13th grade," or the first year out of high school. A counselor at this school believes that the six-year plan positively shapes college opportunity, saying:

I think here, because we have a six-year plan and [students] hear about it from 8th grade to senior year about what A through $\mathrm{G}$ courses are, what are the requirements for a CSU [California State University], a UC [University of California], a private college. I think preparation in terms of hearing about it and awareness, they're well prepared.

The three Georgia schools have developed programs to formally involve teachers in counseling processes. Although these programs are not staterequired, the Georgia low-resource school is "kind of being forced into [the program] because we didn't make A[dequate]Y[early] P[rogress], [and to promote] High Schools That Work program initiatives" (counselor, Georgia low-resource school). These programs involve periodic meetings of teachers with small groups of students to complete lessons developed by a school counselor. The program assumes that teachers will advise the same group of students from the ninth grade through high school graduation, although some participants state that this assumption is not always valid. Moreover, teachers and counselors indicate that only a small share of the advisement program is focused on "college and career preparation." Rather, most of the time is devoted to other functions including distributing report cards, talking to students about the handbook and school rules, and disseminating information. In the words of a teacher at the Georgia low-resource school:

We're in there for 10-20 minutes some mornings and the idea is that we're supposed to develop a bond with these students and nurture them and mentor them or whatever. But I mean we're also [doing other] things and giving out school pictures, so it's not a-it's not as successful as it could be, I would say.

Teacher endorsement may be required to establish similar programs in other schools. A counselor at the California middle-resource school reports that the school had a "staff advisory program" about 15 years ago but "the staff had a hard time with it. ... There were lots of issues with that-our teachers' union. Lots of issues outside of where we had control kind of got involved."

\section{External Entities That Shape College Counseling}

The analyses reveal that several external entities, including district offices, state agencies, and local colleges and universities, shape the availability of college counseling at the 15 schools. 
1. Districts. A district commitment to college opportunity shapes the availability of college counseling in several of the study schools. For example, a commitment to promoting college opportunity was voiced at the California, low-resource school. In the words of a counselor:

I'm going to say, eight years ago or so-who was our principal then? He's now the superintendent-we had a discussion. He said, "Why do schools with similar demographics as ours have a higher rate of kids being accepted to the university?" So it was school mandated. And that started our focus of how we can provide their outreach. And that's when AVID [Advancement Via Individual Determination] sort of came onboard and that's when we had the college center. We started creating it. (counselor, California, low-resource school)

The three Maryland high schools are located in a district with the stated goal: "Every kid goes to college." Participants at all three Maryland schools are aware of this district goal. The relatively low student-to-counselor ratios, as well as the presence of a designated career and college counselor in each of the three Maryland study schools (Table 3), suggest that the commitment to postsecondary educational opportunity is more than rhetoric.

The three Florida schools are also located in a district with a commitment to promoting college opportunity. The district program, adopted more than 20 years ago based on a pilot program in another state, "was really to give relief to the counselors." The program places one or two college counselors at each "full-service high school," including one college counselor in each of our three Florida study schools (Table 3).

Participants in the schools with district-level commitments to college opportunity (Florida and Maryland schools) describe the college-related assistance offered by their respective district offices. In addition to providing a college and career center and coordinator in each school, participants in Florida and Georgia indicate that the district office also provides coordinators with training, information, and support. In Florida, college counselors report engaging in district-sponsored workshops, including financial aid workshops led by the financial aid director of a local college. The district office also collects and disseminates information to the local college advising offices about the availability of scholarships and other topics. The Maryland district office offers workshops on a variety of topics, including such issues as "how to write a better recommendation, how to motivate your students, how to work with the Hispanic population in terms of college" (counselor, Maryland, middle-resource school).

2. States. While the complexity of state financial aid policies may shape the delivery of financial aid assistance (as described above), other state-level forces also influence college counseling in its schools. One state-level force is the availability of state agencies to support college counseling in the state 
schools. Reported reliance on state agencies for college-counseling-related assistance varies across schools, with greater reliance on a state-level agency in Georgia and Pennsylvania than in other states. In Georgia and Pennsylvania, counselors frequently refer to the Georgia Student Finance Commission and the Pennsylvania Higher Education Assistance Authority (PHEAA), respectively, as sources of information. A few California or Maryland counselors report receiving assistance from the California Student Aid Commission and/or the Maryland Higher Education Commission, respectively. No participant at a Florida school referred to a state-level higher education entity as a source of college or financial aid information or support.

Participants suggest that these state agencies serve several roles. First, they conduct annual "free" state and regional workshops to provide "some of that nitty-gritty detail" pertaining to student financial aid (counselor, California, low-resource school). They also disseminate information to counselors via electronic and paper newsletters (counselor, Georgia, middle-resource school). As a result of these efforts, at least one counselor feels that she has "a pretty good handle on" financial aid application procedures (Pennsylvania, middle-resource school).

Counselors also rely on these agencies to address students' financial aid eligibility questions. Rather than address the questions themselves, counselors, especially those in Georgia and Pennsylvania, encourage students to get the information from the state financial aid agency. In the words of one counselor:

I usually, like, refer them either to the [Georgia Student Finance Commission] website or to the 1-800 number just to make sure they're getting the best [and most up-to-date] information as far as how to fill out the form. (Georgia, high-resource school)

Similarly, Pennsylvania counselors defer specific financial aid questions, particularly questions about individual family circumstances, to a regional representative from PHEAA. In the words of a counselor from the Pennsylvania high-resource school, "We use this resource person, and he is pretty accessible to families, if it has to do with-maybe-that FAFSA form, that part of it."

An additional state-level force that shapes college counseling in two of the study schools is the Advancement Via Individual Determination (AVID) program. Although pre-college programs operate at several of the study schools (e.g., Upward Bound at the Pennsylvania low-resource school; Cal-SOAP (Student Opportunity and Access Program) at the California low- and high-resource schools), California's AVID program seems to be an especially important provider of college counseling at the California low- and middle-resource schools. This program received \$7,735,000 from the Cali- 
fornia state legislature in 2006 (California Department of Education, 2006). Districts and schools apply to California Department of Education (CDE) for grants to fund individual programs and work closely with the AVID Center for program administration (California Department of Education, 2006). AVID is targeted toward potential first-generation college students and "not necessarily students that have the highest grades because the ideal AVID student is maybe a student who would slip through the cracks and maybe not succeed ... without that help" (teacher, California low-resource school). At the low-resource California school "students come to AVID at 7:30 to 8:20 every morning for all four years of high school" (counselor) to participate, whereas at the middle-resource California school students participate in AVID in lieu of an elective.

Participants believe that the AVID program promotes students' expectations for, knowledge about, and academic preparation for, college through tutoring, supplemental instruction, visits to college campuses, and other activities. In terms of expectations for college, the following comment is representative: "AVID really motivates and encourages students to think about going straight to the four-year university" (parent, California low-resource school). An 11th grader at the California low-resource school stated that AVID "opens their eyes to all the different campuses that there are around this area, so that, that way, they don't just think that their only option is [the local community college]."

One state-level force that appears to be unrelated to the availability of college counseling at the study schools is a state mandate for counseling. Although 30 of the 50 states, as well as the District of Columbia, mandate school counseling for students in grades 9 through 12 (American School Counselor Association, 2006), of the five study states, only Georgia and Maryland have mandates pertaining to high school counseling. But, at all three schools in Georgia, the ratio of students-to-counselors exceeds the state-mandated student-to-counselor ratio for grades 9 through 12 of 400:1. Student-to-counselor ratios are substantially lower at the Maryland study schools (between 215 and 235 students per counselor) than in Georgia, although the Maryland mandate does not specify counselor ratios (American School Counselor Association, 2006). In Maryland, counselor mandates are funded by the state, whereas local districts are responsible in Georgia. Florida mandates that all districts have a written guidance plan and requires districts to submit a report describing the implementation of the guidance plan, but does not mandate school counselors per se (American School Counselor Association, 2006). California and Pennsylvania have no state counselor mandates (American School Counselor Association, 2006), although, as mentioned in the introduction, in July 2006, California allocated \$200 million in funding for additional school counselors (California Association of School Counselors, 2006a). 
3. Colleges and universities. Individual colleges and universities promote the availability of college counseling at the study schools. At most schools, counselors rely on financial aid staff from local colleges and universities to conduct the school's annual financial aid night for parents.

One study school developed a more formal relationship with a local college to provide college counseling. Specifically, to advance its goal of increasing college enrollment rates, the California low-resource school negotiated an arrangement that allows one of the counselors from a nearby public four-year institution to work at the high school. A counselor explains that, because of the school's efforts, "[This institution] now [has] this prototype where they actually have full-time people placed out at about four or five campuses."

\section{Discussion}

We draw several conclusions from the findings reported above. First, consistent with prior research (McDonough, 1997, 2005a, 2005b; Venezia \& Kirst, 2005), the analyses reveal that all 15 study schools face constraints on the availability of resources for college-related counseling. Constraints take the form of high student-to-counselor ratios, as well as a focus on priorities other than college enrollment (e.g., high school graduation).

Second, the availability of college counseling varies across schools, districts, and states. These variations are reflected in differences across schools and states in the number of students per counselor, as well as in differences in the availability of a dedicated college and career coordinator and center. Ten of the 15 schools in this study have such a center and coordinator, a higher incidence rate than the national data predict. Relatively common at private high schools $(77 \%)$, only $21 \%$ of all public high schools nationwide have a position dedicated to assisting students with postsecondary educational plans and processes (NACAC, 2006).

Third, while prior research shows that college counseling is shaped by school policy and mission (McDonough, 1997), this study shows the additional contribution of external forces, particularly district- and state-level policies and structures. In Florida and Maryland, a district-level commitment to college enrollment is supported, in part, by the presence of a college and career coordinator and center. Although other study schools also have a college and career coordinator and center, the coordinators in Florida and Maryland also receive training, information, and support from district offices. This variation in district-level support may reflect differences across states in the size and structure of districts. The study schools in Florida and Maryland are located in districts with more than 20 high schools, whereas the study schools in California, Georgia, and Pennsylvania are located in districts with only one to three high schools. 
State-level policies and structures also shape the availability of college counseling in the study schools. Perhaps because of the absence of districtlevel support, counselors in Georgia and Pennsylvania rely on their respective state financial aid agencies to provide financial aid information and address students' financial aid questions. Assistance with financial aid from either a district office or state agency is especially important, given that financial aid training is typically not part of a school counselor's formal education (McDonough, 2005a, 2005b). In Florida and Georgia, counselors link academic and financial aid counseling to ensure that students qualify for their state's merit-based financial aid awards. The relative simplicity of the eligibility criteria for the state merit-based aid programs also enables counselors and teachers to more confidently communicate with students about financial aid. In other states, school staff do not provide extensive financial aid assistance to students, at least in part because they are intimidated by the complexity of federal financial aid application processes. Finally, state support for outreach efforts such as AVID apparently increased the availability of college counseling at two of the study schools.

\section{IMPLICATIONS}

Enrolling and succeeding in college requires guidance not only from a student's family but also from high school personnel (Plank \& Jordan, 2001). Support from high school counselors is especially important when parents do not have the knowledge, information, and other resources that are required to adequately guide their children (Furstenberg, Cook, Eccles, Elder, \& Sameroff, 1999; Kerbow \& Bernhardt, 1993; McDonough, 1997; Tierney \& Auerbach, 2004). But this study shows that resource constraints reduce the availability of counselors for one-on-one meetings, shift the focus of counseling to the needs of the school's "typical" or most "needy" students, and require students and their families to initiate contact with school counselors. These findings suggest that students who do not proactively seek contact with counselors and/or attend a high school where college enrollment is not the norm are less likely to receive sufficient college counseling. In other words, students with the greatest need for college counseling likely face the greatest structural barriers to receiving that counseling.

While school structures, missions, policies, and practices certainly play a role in shaping the availability of college counseling (McDonough, 1997), the current inadequacy of college counseling cannot be attributed only to schools. This study illustrates that schools are challenged to improve college counseling not only in the context of fiscal constraints and competing priorities, but also in the context of particular district, higher education, and state policies, practices, and programs.

Therefore, efforts to increase the availability of college counseling must not only recognize the school context, but also the contexts of districts, higher 
education, and the state. In other words, ensuring that all students-not just students who know that they must initiate requests for counseling and not just students who attend particular schools-receive sufficient college counseling requires attention to the positive and negative impacts of external forces on the availability of counseling within a school. The findings from this study suggest several ways that increased attention to external forces would improve the availability of college counseling in the nation's schools.

First, this study suggests that efforts to reduce the complexity of federal and state financial aid policies, application processes, and eligibility criteria would facilitate school counselors' efforts to provide critical financial aid information to students. Such complexity, especially when coupled with an absence of formal financial aid training and high student-to-counselor ratios, reduces the intensity of counselors' financial aid assistance and increases counselors' reliance on other entities (e.g., state student aid associations) to provide this assistance. In contrast, when financial aid processes are simple and transparent, counselors (as well as teachers) not only provide more intensive financial aid assistance but work to ensure that students are academically qualified to receive available assistance.

This recommendation extends the recommendation of the Advisory Committee on Student Financial Assistance (2005) to reduce the complexity of federal financial aid policies and processes to state financial aid policies and processes. While some research suggests that state merit-based aid programs increase the likelihood of enrolling in any type of college or university, increase the likelihood of enrolling at a four-year institution, and reduce the likelihood of enrolling at a public two-year college (Dynarski, 2004), other research suggests that these programs disproportionately benefit students from upper-income families (e.g., Heller \& Marin, 2002). Regardless, this study reinforces the benefits to college counseling of the relative simplicity and transparency of state merit-based programs (such as those in Florida and Georgia) compared to the relatively complex and opaque state need-based aid programs (e.g., the programs in California and Pennsylvania).

Second, school districts should recognize the benefits to college counseling of a district-level commitment to college-going, especially when this philosophical commitment is accompanied by resources and other support. In this study, the availability of college counseling in the Florida and Maryland schools was enhanced by a district-level commitment to college enrollment, a commitment that was manifest by a district-supported college counselor, college and career center, and training and professional development for college counselors.

Third, schools and higher education institutions should identify opportunities to build mutually beneficial collaborations. This study suggests that both schools and higher education institutions benefit from the common 
practice of higher education staff conducting the annual financial aid night at local high schools. For their part, schools benefit because local experts provide financial aid information, while colleges and universities benefit from direct access to potential applicants and their families. By working to identify other collaborative opportunities, schools and higher education institutions will not only advance their own goals but also maximize the availability of college counseling in the context of scarce resources.

In conclusion, because this study demonstrates that the school, district, and state context shapes the availability of counseling, a one-size-fits-all approach to improving college counseling is likely to be ineffective. In other words, as suggested by the conceptual model (Perna, 2006; Perna \& Thomas, 2006), efforts to improve the availability of college counseling must reflect the overlapping contexts of school, district, higher education, and state. Nonetheless, the results of this study also suggest that the availability of college counseling may be enhanced by explicitly and intentionally making use of all available resources, including teachers, district offices, and state agencies, and local colleges and universities, and by recognizing the intended and unintended consequences of the various layers of context.

\section{REFERENCES}

Advisory Committee on Student Financial Assistance. (2002). Empty promises: The myth of college access in America. Washington, DC: Author.

Advisory Committee on Student Financial Assistance. (2005). The student aid gauntlet: Making access to college simple and certain. Washington, DC: Author.

American School Counselor Association. (2006). State school counseling mandates. Retrieved September 28, 2006, from www.schoolcounselor.org/content. asp? contentid $=424$.

Ballard, M. B., \& Murgatroyd, W. (1999). Defending a vital program: School counselors define their roles. NASPA Bulletin, 83(603), 19-26.

Baum, S., \& Payea, K. (2004). Education pays 2004: The benefits of higher education for individuals and society. Washington, DC: College Board.

Beesley, D. (2004). Teachers' perceptions of school counselor effectiveness: Collaborating for student success. Education, 125(2), 259-269.

California Association of School Counselors (2006a). School counselor funding to dramatically increase. San Bernardino, CA: Author. Retrieved October 6, 2006, from www.school-counselor-ca.org/legislative.cfm.

California Association of School Counselors. (2006b). Bill analysis: AB 1802, section 13. San Bernardino, CA: Author. Retrieved October 6, 2006, from www. school-counselor-ca.org/legislative.cfm.

California Department of Education (2006). Advancement Via Individual Determination (AVID). Retrieved October 11, 2006, from http://www.cde.ca.gov/ ci/gs/ps/avidgen.asp. 
Chapman, D. W., DeMasi, M., \& O’Brien, C. (1991). Parents' perceptions of the effectiveness of public school counselors in college advising. School Counselor, $38,268-278$.

Dynarski, S. (2004). The new merit aid. In C. M. Hoxby (Ed.), College choices: The economics of where to go, when to go, and how to pay for it (pp. 63-100). Chicago: University of Chicago Press.

Ellwood, D. T., \& Kane, T. J. (2000). Who is getting a college education? Family background and the growing gaps in enrollment. In S. \&. W. J. Danzinger (Eds.), Securing the future: Investing in children from birth to college (pp. 283-324). New York: Russell Sage Foundation.

Freeman, B., \& Coll, K. M. (1997). Factor structure of the role questionnaire: A study of high school counselors. Measurement and Evaluation in Counseling and Development, 30, 32-40.

Furstenberg, F. F., Cook, T. D., Eccles, J., Elder, G. H., \& Sameroff, A. (1999). Managing to make it: Urban families and adolescent success. Chicago: University of Chicago Press.

Hamrick, F. A., \& Hossler, D. (1996). Diverse information-gathering methods in the postsecondary decision-making process. Review of Higher Education, 19, 179-198.

Heller, D., \& Marin, P. (Eds.) (2002). Who should we help? The negative social consequences of merit scholarships. Cambridge, MA: The Civil Rights Project at Harvard University.

Horn, L. J., Chen, X., \& Chapman, C. (2003). Getting ready to pay for college: What students and their parents know about the cost of college tuition and what they are doing to find out. (NCES 2003-030). Washington, DC: U.S. Department of Education, Institute of Education Sciences.

Kane, T. J. (1999). The price of admission: Rethinking how Americans pay for college. Washington, DC: Brookings Institution Press.

Kerbow, D., \& Bernhardt, A. (1993). Parental intervention in the school: The context of minority involvement. In B. Schneider \& J. S. Coleman (Eds.), Parents, their children, and school (pp. 115-145). Boulder, CO: Westview Press.

Libsch, M., \& Freedman-Doan, P. (1995). Perceptions of high school counseling activities: Response differences according to college plans. NASSP Bulletin, 79(570), 51-60.

Linnehan, F. (2006). High school guidance counselors: Facilitators or preemptors of social stratification in education? Paper presented at the annual meeting of the Academy of Management, Atlanta, GA.

McDonough, P. M. (1997). Choosing colleges: How social class and schools structure opportunity. Albany: State University of New York Press.

McDonough, P. M. (2005a). Counseling and college counseling in America's high schools. In D. A. Hawkins \& J. Lautz (Eds.), State of college admission (pp. 107-121). Washington, DC: National Association for College Admission Counseling.

McDonough, P. M. (2005b). Counseling matters: Knowledge, assistance, and organizational commitment in college preparation. In W. G. Tierney, Z. B. Corwin, 
\& J. E. Colyar (Eds.), Preparing for college: Nine elements of effective outreach (pp. 69-88). Albany: State University of New York Press.

McDonough, P. M., antonio, a. 1., \& Trent, J. W. (1997). Black students, Black colleges: An African American college choice model. Journal for a Just and Caring Education, 3, 9-36.

NACAC. National Association for College Admissions Counselors. (2006). State of college admission, 2006. Washington, DC: Author.

NASSGAP. National Association of State Student Grant and Aid Programs. (2007). 37th annual survey report on state-sponsored student financial aid: 2005-06 academic year. Retrieved on July 23, 2007, from www.nassgap.org.

NCES. National Center for Education Statistics. (2003). Enrollment in postsecondary institutions, fall 2001 and financial statistics, fiscal year 2001. Washington, DC: Author. (NCES 2004-155)

NCES. National Center for Education Statistics. (2004). Digest of Education Statistics 2003. Washington, DC: Author. (NCES 2005-025)

Paulsen, M. B., \& St. John, E. P. (2002). Social class and college costs: Examining the financial nexus between college choice and persistence. Journal of Higher Education, 73, 189-236.

Perna, L. W. (2004). Impact of student aid program design, operations, and marketing on the formation of family college-going plans and resulting college-going behaviors of potential students. Boston: The Education Resources Institute (TERI).

Perna, L. W. (2005). The key to college access: A college preparatory curriculum. In W. G. Tierney, Z. B. Corwin, \& J. E. Colyar (Eds.), Preparing for college: Nine elements of effective outreach (pp. 113-134). Albany: State University of New York Press.

Perna, L. W. (2006). Studying college choice: A proposed conceptual model. In J. C. Smart (Ed.), Higher education: Handbook of theory and research (Vol. 21, pp. 99-157). Dordrecht, NL: Springer.

Perna, L. W., \& Thomas, S. L. (2006). A framework for reducing the college success gap and promoting success for all. Washington, DC: National Postsecondary Education Cooperative.

Perna, L. W., \& Titus, M. (2004). Understanding differences in the choice of college attended: The role of state public policies. Review of Higher Education, 27, 501-525.

Perna, L. W., \& Titus, M. (2005). The relationship between parental involvement as social capital and college enrollment: An examination of racial/ethnic group differences. Journal of Higher Education, 76, 485-518.

Plank, S. B., \& Jordan, W. J. (2001). Effects of information, guidance, and actions on postsecondary destinations: A study of talent loss. American Educational Research Journal, 38, 947-979.

Rosenbaum, J. E. (2001). Beyond college for all: Career paths for the forgotten half. New York: Russell Sage Foundation.

Rosenbaum, J. E., Miller, S. R., \& Krei, M. S. (1996). Gatekeeping in an era of more open gates: High school counselors' views of their influence on students' college plans. American Journal of Education, 104, 257-278. 
St. John, E. P. (2003). Refinancing the college dream: Access, equal opportunity, and justice for taxpayers. Baltimore: Johns Hopkins University Press.

St. John, E. P., \& Asker, E. H. (2001). The role of finances in student choice: A review of theory and research. In M. B. Paulsen, \& J. C. Smart (Eds.), The finance of higher education: Theory, research, policy, and practice (pp. 419-438). New York: Agathon Press.

Stanton-Salazar, R. D. (1997). A social capital framework for understanding the socialization of racial minority children and youth. Harvard Educational Review, 67, 1-40.

Springer, W. L., Cunningham, A. F., O’Brien, C. T., \& Merisotis, J. (1998). It's all relative: The role of parents in college financing and enrollment. (New Agenda Series, Volume 1, Number 1) Indianapolis, IN: USA Group Foundation.

Thomas, S. L., \& Perna, L. W. (2004). The opportunity agenda: A reexamination of postsecondary reward and opportunity. In J. C. Smart (Ed.), Higher education: Handbook of theory and research (Vol. 19, pp. 43-84). Dordrecht, NL: Kluwer Academic Publishers.

Tierney, W. G., \& Auerbach, S. (2004). Toward developing an untapped resource: The role of families in college preparation. In W. G. Tierney, Z. Corwin, \& J. E. Colyar (Eds.), Preparing for college: Nine elements of effective outreach. Albany: State University of New York Press.

Tomás Rivera Policy Institute at University of Southern California. (2004). Caught in the financial aid information divide: A national survey of Latino perspectives on financial aid. Reston, VA: The Sallie Mae Fund.

Tornatzky, L. G., Cutler, R., \& Lee, J. (2002). College knowledge: What Latino parents need to know and why they don't know it. Claremont, CA: The Tomás Rivera Policy Institute.

Venezia, A., \& Kirst, M. W. (2005). Inequitable opportunities: How current education systems and policies undermine the chances for student persistence and success in college. Educational Policy, 19, 293-307.

Venezia, A., Kirst, M. W., \& antonio, a. 1. (2003). Betraying the college dream: How disconnected $\mathrm{K}-12$ and postsecondary education systems undermine student aspirations. Stanford, CA: The Bridge Project.

WICHE. Western Interstate Commission for Higher Education. (2003). Knocking at the college door: Projections of high school graduates by state, income, and race/ethnicity, 1988 to 2018. Boulder, CO: Author.

Yin, R. K. (2003a). Applications of case study research (2nd ed.). Applied Social Research Methods Series, Volume 34. Thousand Oaks, CA: Sage Publications.

Yin, R. K. (2003b). Case study research: Design and methods (3rd ed.). Applied Social Research Methods Series, Volume 5. Thousand Oaks, CA: Sage Publications. 